\title{
ЧАСТОТА ВИЯВЛЕННЯ АРТЕРІАЛЬНОЇ ГІПЕРТЕНЗІЇ СЕРЕД ПАЦІЄНТІВ ВІДОМЧОї ПОЛІКЛІНІКИ
}

\author{
Н. В. Карел, Н. І. Ярема, Н. І. Рега, С. О. Ястремська \\ ДВНЗ «Тернопільський національний медичний університет \\ імені І. Я. Горбачевського МОЗ Украӥни"
}

У статті наведено статистичні дані щодо частоти виявлення артеріальної гіпертензії на дільниці обслуговування поліклінічного відділу військово-медичної служби управління СБУ в Тернопільській області.

\section{FREQUENCY OF ARTERIAL HYPERTENSION OCCURRENCE IN PATIENTS OF DISTRICT INSTITUTIONAL POLYCLINIC}

\author{
N. V. Karel, N. I. Yarema, N. I. Reha, S. O. Yastremska \\ I. Horbachevsky Ternopil National Medical University
}

The article represents the statistical evidence of the frequency of arterial hypertension occurrence in patients of district institutional polyclinic, of military medical service of Security Service of Ukraine in Ternopil region.

Вступ. Для України в останні десятиліття актуальною проблемою залишаються кардіологічні захворювання. Дослідження, які проводили за останні десятиліття, вказують на невпинне зростання поширеності та смертності від хвороб системи кровообігу [1-3]. Провідною патологією в їх структурі залишається гіпертонічна хвороба (ГХ), частка якої коливається в межах 40-46 \%, а темпи приросту становлять 58,0 \% [4-6]. Вона визначає як соціальну, так і економічну складову впливу на здоров'я населення [5, 7]. Протягом останніх років також відзначають тенденцію до істотного зростання цієї патології $[1,8]$. Основними причинами виникнення та поширення ГХ і їі ускладнень залишаються класичні чинники ризику: надмірна маса тіла та нераціональне харчування, зловживання алкоголем, тютюнокуріння, недостатня фізична активність, а також національний економічний стан, необізнаність пацієнтів і нераціональне приймання антигіпертензивних середників [9-11].

Проблема артеріальної гіпертензії (АГ) давно вийшла за рамки суто медичної. Сьогодні весь світ визначає ії як соціальну проблему, яка впливає на здоров'я суспільства і тривалість життя громадян. Україна не $\epsilon$ винятком: рівень поширеності цього захворювання та смертності від нього в нашій країні () Н. В. Карел, Н. І. Ярема, Н. І. Рега, С. О. Ястремська, 2019 досить високий $[12,13]$. Протягом останніх двох десятиліть в Україні істотно зросла поширеність (у 2,3 раза) та захворюваність (у 1,9 раза) на ГХ. Найбільше ці показники змінилися у південному та південно-східному районах України [11].

Несприятлива епідеміологічна ситуація, що склалася в Україні щодо гіпертонічної хвороби і спричинених нею ускладнень, вимагає негайного вирішення на державному рівні. За умов реформування системи охорони здоров'я України особливого значення набуває запровадження якісно нових заходів щодо профілактики захворювань та діяльності з формування здорового способу життя. За даними офіційної статистики МО3, кожна третя людина дорослого віку на сьогодні страждає від ГХ різної форми. Щорічно при зверненні людей вперше до лікувально-профілактичних закладів виявляють понад 1 млн хворих на АГ [13]. Вона є одним із основних чинників серцевосудинних захворювань. Відомо, що наявність високого артеріального тиску (АТ) провокує та прискорює розвиток атеросклерозу, що, в свою чергу, суттєво (в 3-4 рази) підвищує захворюваність на ішемічну хворобу серця (IXC) та інсульт, а також на серцеву та ниркову недостатність, в 7 разів частіше спричиняє порушення мозкового кровообігу. якщо проаналізувати структуру загальної смертності населення України, 
стає очевидним: 66,3 \% смертей є наслідком хвороб системи кровообігу. Тому усунення АГ, яка є вагомим чинником зменшення ризику серцево-судинних захворювань, сприятиме поліпшенню стану здоров'я суспільства в цілому [12].

Основна частина. Проведено вивчення частоти АГ на дільниці обслуговування поліклінічного відділу військово-медичної служби управління СБУ в Тернопільській області.

Станом на 01 січня 2019 р. кількість населення на цій дільниці становила 1586 дорослих.

Згідно з даними «Паспорта дільниці», проаналізовано віковий склад населення дільниці (табл. 1).

\section{Таблиця 1. Віковий склад населення дільниці}

\begin{tabular}{|l|c|}
\hline Вікова категорія (роки) & Кількість людей \\
\hline $18-24$ & 248 \\
\hline $25-34$ & 368 \\
\hline $35-44$ & 321 \\
\hline $45-54$ & 335 \\
\hline $55-64$ & 194 \\
\hline $65-74$ & 62 \\
\hline Старші 75 & 58 \\
\hline
\end{tabular}

Як наведено в таблиці 1, основну масу дільниці складає працездатне населення (люди молодого і середнього віку), що пояснюється відомчим характером дільниці.

Людей працездатного віку було 1372 (86,5%), пенсіонерів - 214 (13,5 \%). Порівняно невисока питома вага непрацездатного населення пояснюється відомчим характером дільниці.

Поділ населення за статтю наведено на рисунку 1.

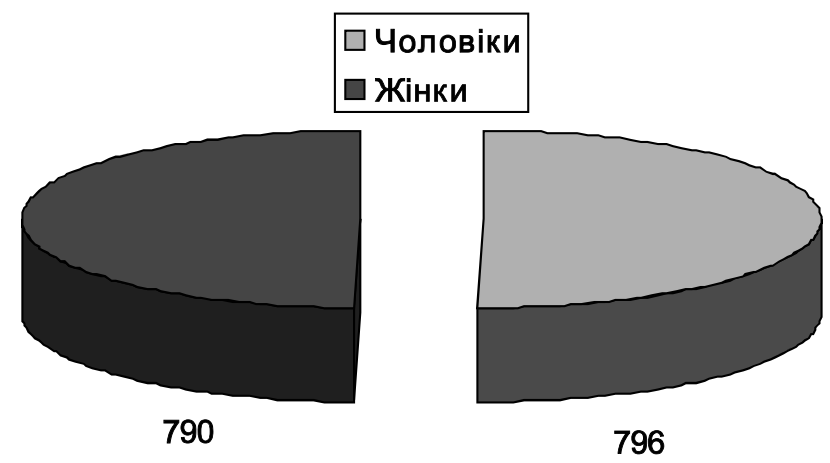

Рис. 1. Поділ населення на дільниці за статтю.

Як видно з рисунка 1, на дільниці перебуває приблизно однакова кількість чоловіків і жінок.

Поділ населення дільниці за групами здоров'я наведено на рисунку 2.

Як видно з рисунка 2, 376 чоловік (23,7 \%) мають хронічні захворювання, у тому числі АГ.

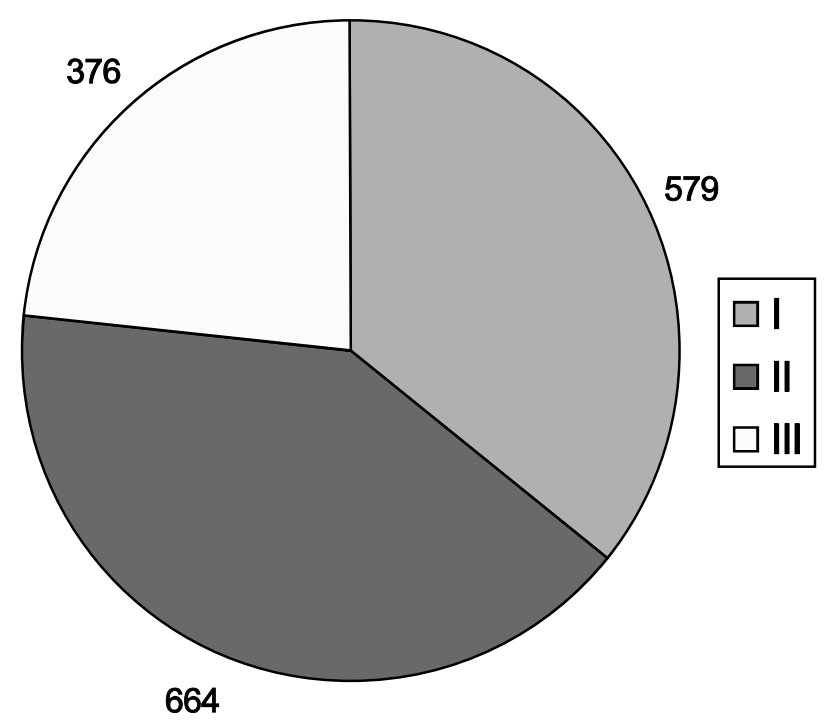

Рис. 2. Розподіл населення на дільниці за групами здоров'я.

Порівнявши ці дані із кількістю непрацездатного населення (відповідно 13,5 \% населення дільниці), стає зрозуміло, що, незважаючи на відомчий характер дільниці, на хронічні захворювання хворіють і молоді працездатні люди.

Всього станом на 01 січня 2019 р. на диспансерному обліку перебуває 193 людини з АГ та 85 людей із поєднанням IXC з АГ (табл. 2).

\section{Таблиця 2. Питома вага хворих на артеріальну гіпертензію}

\begin{tabular}{|c|c|c|c|}
\hline \multirow{2}{*}{$\begin{array}{c}\text { Назва } \\
\text { нозології }\end{array}$} & $\begin{array}{c}|c| \\
\text { абсолютне } \\
\text { число } \\
\text { (люди) }\end{array}$ & $\begin{array}{c}\text { Кількість хворих } \\
\text { стосовно } \\
\text { населення } \\
\text { дільниці }\end{array}$ & $\begin{array}{c}\text { стосовно числа } \\
\text { всіх пацієнтів із } \\
\text { хронічними за- } \\
\text { хворюваннями }\end{array}$ \\
\hline АГ & 193 & 12,17 & 51,33 \\
\hline ІХС + АГ & 85 & 5,36 & 22,61 \\
\hline Разом & 278 & 17,53 & 73,94 \\
\hline
\end{tabular}

Як видно із таблиці 2, АГ було виявлено у кожного шостого жителя дільниці, а серед випадків усіх хронічних захворювань АГ спостерігали практично у трьох із кожних чотирьох пацієнтів.

Висока питома вага АГ зумовлює подальші шляхи пошуку ефективних методів профілактики та лікування цього захворювання.

Висновки. 1. У проаналізованій популяції населення частки людей з АГ складає 17,53 \% від усього населення дільниці, серед них хворі на ГХ становлять $12,7 \%$, а на поєднання IXC з АГ - 5,36 \% від населення дільниці. 
2. Серед усіх диспансерних хворих дільниці частка пацієнтів з АГ складає 73,94 \% випадків, зокрема хворі на ГХ становлять 51,33 \%, а на поєднання IXC з АГ 22,61 \% від всіх диспансерних хворих.

\section{СПИСОК ЛІТЕРАТУРИ}

1. Основні епідеміологічні закономірності хвороб системи кровообігу і гіпертонічної хвороби в Україні / О. М. Голяченко, А. Г. Шульгай, А. О. Голяченко [та ін.] // Вісник соціальної гігієни та організації охорони здоров'я України. - 2010. - № 4. - С. 9-15.

2. Особливості захворюваності дорослого населення України на хвороби системи кровообігу /Т. К. Кульчицька, Т. С. Грузєва, Г. О. Слабкий [та ін.] // Вісник соціальної гігієни та організації охорони здоров'я України. - 2001. № 2. - С. 34-38.

3. Теренда Н. О. Прогностична оцінка захворюваності та поширеності хвороб системи кровообігу / Н. О. Теренда // Вісник соціальної гігієни та організації охорони здоров'я України. - 2014. - № 4 (62). - С. 31-35.

4. Динаміка захворюваності на хвороби системи кровообігу у жителів міста Чернівці за 1991-2010рр. / С. В. Білецький, Л.В.Боднарюк, Т. В. Казанцева, Ю. М. Бондар // Буковинський медичний вісник - 2011. - Т. 15, № 2. - С. 168-172.

5. Дячук Д. Д. Щодо захворюваності дорослого населення України на неінфекційні хвороби / Д. Д. Дячук // Вісник соціальної гігієни та організації охорони здоров'я України. - 2011. - № 1. - С. 19-23.

6. Крапівіна А. А. Захворюваність на хвороби системи кровообігу та їх поширеність серед дорослого населення України в 2010 році: гендерний аспект / А. А. Крапівіна // Україна. Здоров'я нації. - 2011. - № 4 (20). - С. 12-18.

7. Сучасний стан первинної інвалідності населення працездатного віку в Україні / А. В. Іпатов, О. В. Сергієні,
3. Актуальна розробка ефективних методів профілактики та лікування АГ в осіб усіх вікових груп.

Т. Г. Войтчак, В. В. Коваленко // Вісник соціальної гігієни та організації охорони здоров'я України. - 2006. - № 1. с. 32-37.

8. Анализ эпидемиологической ситуации с церебральной сосудистой патологией и некоторыми другими болезнями системы кровообращения, сложившейся в Украине в 1980-2001 гг. / Н. В. Калашников, С. М. Кузнецова, Л. М. Ена [и др.] // Журнал АМН України. - 2004. - Т. 10, № 4. - С. 716-736.

9. Клименко В. І. Хвороби системи кровообігу як медико-соціальна державна проблема / В. І. Клименко // Вісник соціальної гігієни та організації охорони здоров'я України. - 2007. - № 4. - С. 17-21.

10. Горбась І. М. Фактори ризику серцево-судинних захворювань: поширеність і контроль [Електронний ресурс] / І. М. Горбась. - Режим доступу : http://health-ua. com/article/2229.html. - Назва з екрана.

11. Теренда Н. О. Основні тенденції загальної та первинної захворюваності на гіпертонічну хворобу в Україні / Н. О. Теренда // Вісник соціальної гігієни та організації охорони здоров'я України. - 2015. - № 4 (66). - С. 39-43.

12. Артеріальна гіпертензія. Оновлена та адаптована клінічна настанова, заснована на доказах (2012 рік) / Є. П. Свіщенко, А. Е. Багрій, Л. М. Єна [та ін.] // Артериальная гипертензия. - 2012. - № 1 (21). - С. 96-119.

13. Уніфікований клінічний протокол медичної допомоги. Артеріальна гіпертензія. Первинна медична допомога (догоспітальний етап). Вторинна (спеціалізована) медична допомога (2012 рік) // Артериальная гипертензия. - 2012. - № 1 (21). - С. 67-95.

Отримано 01.02.19 